\title{
First evidence of the presence of genotype- 1 of Japanese encephalitis virus in Culex gelidus in Indonesia
}

\author{
Triwibowo Ambar Garjito ${ }^{1,2,3^{*}}$ D, Mega Tyas Prihatin ${ }^{1}$, Lulus Susanti ${ }^{1}$, Dhian Prastowo ${ }^{1}$, Siti Rofiatus Sa'adah ${ }^{1}$, \\ Yulian Taviv ${ }^{4}$, Tri Baskoro Tunggul Satoto ${ }^{5}$, Joko Waluyo ${ }^{1}$, Sylvie Manguin ${ }^{2,3}$ and Roger Frutos ${ }^{2,6,7}$
}

\begin{abstract}
Background: Japanese encephalitis has become a public health threat in Indonesia. Three genotypes have been recorded in Indonesia, i.e. genotype II (GII), genotype III (GIII) and genotype IV (GIV). Genotype I (GI) and genotype V (GV) have never been reported in Indonesia.

Results: A Japanese encephalitis virus (JEV) belonging to the genotype l-a (Gl-a) has been isolated for the first time from a Culex gelidus mosquito in the Province of Jambi, Indonesia. This virus is related to a 1983 isolate from Thailand whereas the infected $C x$. gelidus mosquito belonged to a Chinese haplotype.

Conclusions: Surveillance of JEV and mosquito dissemination is recommended.
\end{abstract}

Keywords: Japanese encephalitis, Genotype I, Indonesia, Culex gelidus

\section{Background}

The Japanese encephalitis virus (JEV) is a mosquito-borne flavivirus that has become a public health threat in Asia, including Indonesia. JEV is transmitted to humans through mosquito bites, especially of Culex species, from amplifier animals such as pigs. JEV can cause severe central nervous system disorders with high mortality or permanent neurological sequelae [1].

In Indonesia, JEV was first isolated from mosquitoes in West Java in 1972. Since then, encephalitis cases have been reported in several hospitals and currently Japanese encephalitis (JE) has become widespread and endemic across 32 out of 34 Indonesian provinces [2]. JEV originated from the IndoMalayan region and further evolved into five genotypes. Until now, only three genotypes have been recorded in Indonesia, i.e. genotype II (GII), genotype III (GIII) and genotype IV (GIV). Furthermore, GIV has only been described in mosquitoes in Indonesia [3]. Although JEV originated from the Indo-Malaysia

\footnotetext{
* Correspondence: triwibowo@litbang.depkes.go.id; triwibowoambar.garjito@etu.umontpellier.fr

${ }^{1}$ Institute for Vector and Reservoir Control Research and Development (NIHRD-MoH), Salatiga, Indonesia

¿Université de Montpellier, Montpellier, France

Full list of author information is available at the end of the article
}

region about 1695 years ago, genotype I (GI) most likely originated in Thailand for clade GI-a and Vietnam for clade GI-b about 193 years ago and has never been reported in Indonesia [3, 4]. Genotype I is associated with human encephalitis in China, Japan, India, Korea, Taiwan, Thailand and Vietnam [4]. GI JEV is an epidemic genotype with equal virulence as GIII JEV, the genotype most frequently associated with outbreaks in Asia [5].

\section{Methods}

Jambi, Sumatra, is a province confirmed as a JE endemic area. Entomological investigation was conducted at six sentinel sites in the Bungo, Tanjung Jabung Barat and Sarolangun Districts from May to June 2017 (Fig. 1). Mosquito collections were conducted using human landing, direct collection around cattle and animal baited trap collection. Sampling was conducted from 18:00 h to 6:00 $\mathrm{h}$ at every sentinel site. After identification, mosquitoes were sorted according to locality and date, and stored in RNAlater (Ambion-Thermo Fischer Scientific, Waltham, USA) at $-80{ }^{\circ} \mathrm{C}$ until further analysis. The excised head and thorax of each mosquito were homogenized in a sterile homogenizer, RNA was extracted by 




Fig. 1 Map of Indonesia and of the province of Jambi. The Bungo, Tanjung Jabung Barat and Sarolangun districts where the sampling was conducted are located on the map. Black dots represent the sampling locations in each district (6 per district)

silica-based methods (RNA-easy minikit, Qiagen, Hilden, Germany) and sample aliquots were pooled together by groups of 25. JEV detection was carried out by one step RT-PCR on the NS3 gene [6] using the consensus primers FP (5'-AGA GCG GGG AAA AAG GTC AT-3') and RP (5'-TTT CAC GCT CTT TCT ACA GT-3'). The PCR reaction was performed as previously described [7]. The primers corresponded to a 162-bp product (Fig. 2). JEV genotyping from positive samples was performed using the envelope (E) gene sequence. The $\mathrm{E}$ gene was amplified using the primers JEV-Ef (5'-TGY TGG TCG CTC CGG



Fig. 2 Electrophoretic analysis of JEV NS3 PCR products. Lane K+, positive control; Lane K-, negative control; Lane 107, Sample 107 (JE/mosq/jambi107/2017)
CTT A-3') and JEV-Er (5'-AAG ATG CCA CTT CCA CAY CTC-3') [7] using Superscript III one-step RT-PCR with platinum TaqDNA polymerase (Invitrogen, Life Technologies, Carlsbad, USA). For amplification of the JEV gene, initial denaturation was carried out at $93{ }^{\circ} \mathrm{C}$ for $30 \mathrm{~s}$ followed by 40 cycles of $94{ }^{\circ} \mathrm{C}$ for $15 \mathrm{~s}, 53{ }^{\circ} \mathrm{C}$ for $30 \mathrm{~s}$ and $68^{\circ} \mathrm{C}$ for $1 \mathrm{~min} 30 \mathrm{~s}$, with a final extention step at $68^{\circ} \mathrm{C}$ for 5 min. Products were electrophoresed in $2 \%$ agarose gel and vizualized by SYBR safe DNA gel staining (Invitrogen, Life Technologies).

The amplification products were then purified using Illustra ExoProSTar (GE Healthcare Life Sciences, Tokyo, Japan). Sequencing of the amplified gene $\mathrm{E}$ was performed using the primers JEV-Ef and JEV-Er mentioned above and ABI BigDye terminator Cycle Sequencing Kit v.3.1 (Applied Biosystems, Austin, USA). Prior to sequencing, a PCR product purification step was performed using BigDye Xterminator Purification Kit (Applied Biosystems). Sequence data were obtained through the Sanger method using an automatic DNA sequencer (Applied Biosystems 3500 Genetic Analyzer) and analyzed using the Sequencing Analysis 6 program (Applied Biosystems).

The phylogenetic tree was built using the maximum likelihood method with Tamura Nei (TN93) as evolutionary model. Node bootstraps were calculated with 2000 
Table 1 Culex mosquitoes captured in the Province of Jambi, Indonesia

\begin{tabular}{lll}
\hline Species & No. of pools & No. of samples \\
\hline Cx. fuscocephalus & 2 & 10 \\
Cx. gelidus & 34 & 850 \\
CX. quinquefasciatus & 23 & 500 \\
Cx. tritaeniorhynchus & 2 & 50 \\
Cx. vishnui & 3 & 75 \\
Total & 64 & 1485 \\
\hline
\end{tabular}

replicates. Sequences were compared to $16 \mathrm{JEV}$ reference sequences from GenBank comprising 6 GI-b, 2 GI-a, 2 GII, 3 GIII, 2 GIV, 1 GV and 2 MVEV (Murray Valley encephalitis virus) sequences used as outgroups. The mosquito in which the JEV was detected was genotyped using the cytochrome $c$ oxidase subunit 1 gene $(\operatorname{cox} 1)$ as a target. The $\operatorname{cox} 1$ gene was amplified using the primers CIN2087 (5'-AAT TTC GGT CAG TTA ATA ATA TAG-3') and TYJ-1460 (5'-TAC AAT TTA TCG CCT AAA CTT CAG CC-3') as previously described [8].

\section{Results and discussion}

A total of 1485 Culex mosquitoes were collected and analyzed. These mosquitoes belonged to five different species: Culex gelidus, Culex quinquefasciatus, Culex tritaeniorhynchus, Culex vishnui and Culex fuscocephalus (Table 1). The species displaying the highest prevalence were $C x$. geli$d u s$ and $C x$. quinquefasciatus. JEV was detected in only one $C x$. gelidus mosquito. Positive detection of JEV was confirmed by sequencing and blast analysis. The gene E sequence from JE/mosq/Jambi107/2017 was deposited in GenBank under the accession number MK032889. The gene $\mathrm{E}$ phylogenetic analysis (Fig. 3) indicated that JE/mosq/ Jambi107/2017 belonged to the clade GI-a of JEV and was closely related to a genotype I-a isolate from Thailand (GenBank: KF192510.1). The GI-a clade of genotype I was described until now only in Thailand and Cambodia. The genotype I of JEV is found only from $10^{\circ} \mathrm{N}$ up to $35^{\circ} \mathrm{N}$ with two separate clades $[3,4]$. The clade GI-a is found in Thailand and Cambodia from where one case was introduced to Australia [3, 4]. The clade GI-b is found in Vietnam, China, Taiwan, Korea, India and Japan [3, 4].

To our knowledge, this is the first detection of GI JEV in Indonesia. A replacement of GIII by GI was reported throughout Asia and Australia since 1979 [9]. A similar phenomenon could be underway in Indonesia and should be investigated more thoroughly. The mode of introduction of GI in several countries has not been clearly established but a narrower vector host range and a higher replication capacity of GI in mosquitoes has been described [3]. The cox1 haplotype of the Cx. gelidus mosquito infected with JE/mosq/ Jambi107/2017 (GenBank: MK045308) was found to be very close to a haplotype previously described in China (GenBank: MF179173). Blast results for the two best hits were as follows: GenBank: MF179173, maximum score 861, total score 861 , total coverage $100 \%$, E value 0.0 , identity $97 \%$; GenBank: MF179172, maximum score 856, total score 856, total coverage $100 \%$, E value 0.0, identity 97\%. Culex gelidus is a good vector of JEV with an invasive capacity and a

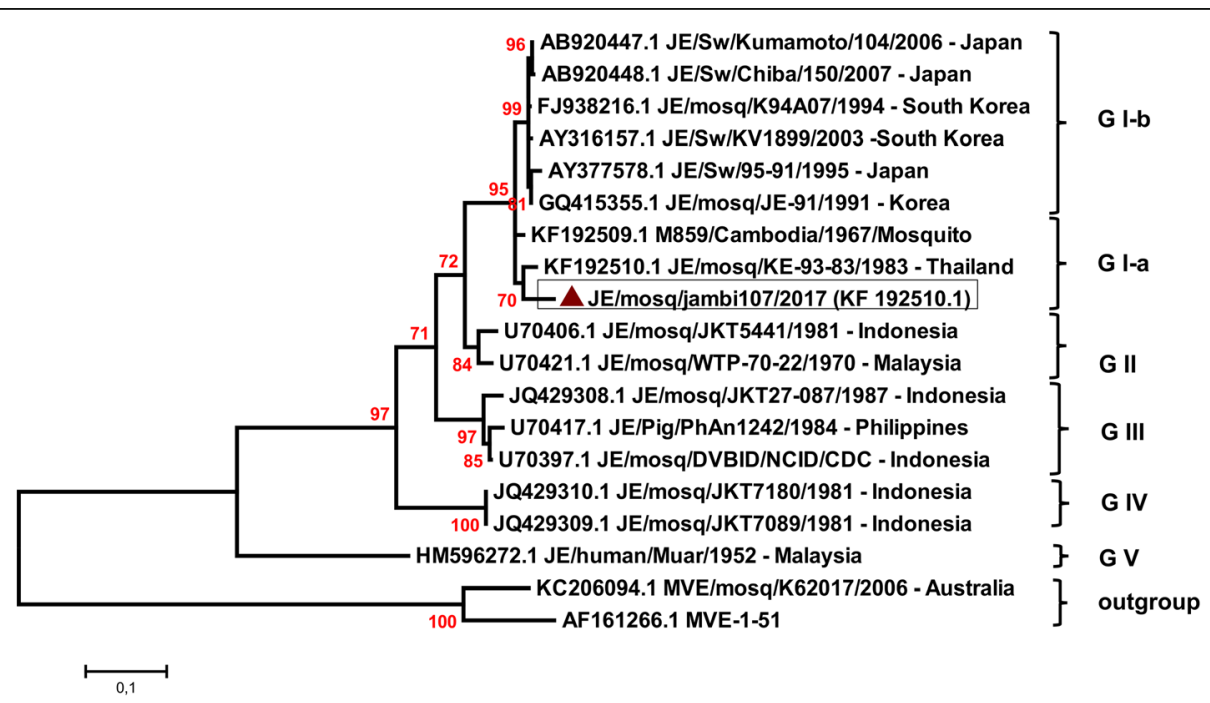

Fig. 3 Phylogenetic tree positioning JE/mosq/jambi107/2017 in comparison to $16 \mathrm{JEV}$ reference strains. Reference JEV sequences were obtained from GenBank. Reference sequences are identified by their accession number. JE/mosq/jambi107/2017 (KF192510.1) is shown in a box and marked by a red triangle. The sequence from this study is marked by a red triangle. The phylogenetic analysis was performed with the maximum likelihood method using the Tamura-Nei model (TN93) as evolutionary model. Node bootstraps were calculated with 2000 replicates. Bootstrap values $<70$ are not shown. The tree was rooted with 2 Murray Valley encephalitis virus (MVEV) sequences as outgroups. The scale-bar indicates the number of nucleotide subtitutions per site 
potential for being transported over long distance by boats, planes or road transportation [10].

\section{Conclusions}

The role of specific mosquito populations in the introduction and dissemination of GI JEV through commercial routes should be investigated. GI, which is currently replacing GIII in Asia, could not be detected in cerebrospinal fluid by JEV-specific IgM antibodies raised against GIII JEV [3]. There is thus a risk of misdiagnosis in the presence of GI. Furthermore, all vaccines currently available against JEV are derived from GIII JEV and several studies have reported human confirmed cases with GI JEV infection in areas where effective JEV vaccination programs exist $[11,12]$. There is thus, in addition to misdiagnosis, a risk of lack of efficient protection associated with the extension of GI. Further studies and strengthened JE surveillance should be implemented to assess the distribution of GI JEV in Indonesia and health authorities must be alerted in order to address potential risks to public health.

\section{Abbreviations}

JEV: Japanese encephalitis virus; G: genotype; cox1: cytochrome c oxidase subunit 1; MVEV: Murray Valley encephalitis virus

\section{Acknowledgments}

The authors express their gratitude to the head of the National Institute of Health Research and Development, the Ministry of Health of Indonesia for permission to do the analyses. The authors would also like to thank the people in the study areas for cooperating during the entomological surveys, all field mosquito collectors from the Rikhus Vektora project in Jambi, and the experts and technical team of the Rikhus Vektora project for fruitful discussions.

\section{Funding}

The research was supported by the Institute for Vector and Reservoir Control Research and Development, National Institute of Health Research and Development, Ministry of Health Indonesia under the project Rikhus Vektora 2017. SM and RF were supported by the Université de Montpellier, IRD and CIRAD, Montpellier, France.

\section{Availability of data and materials}

Data supporting the conclusions of this article are included within the article. Raw data are available from corresponding author upon reasonable request. Sequences are deposited in the GenBank database under the accession numbers MK032889 and MK045308.

\section{Authors' contributions}

TAG, JW, TTS and LS conceived and designed the experiments. TAG, MTP, LS DP, SRS, YT, TBTS and DP performed the experiments. TAG, MTP, SM and RF analyzed the data. TAG, TTS, SM and RF wrote the manuscript. All authors read and approved the final manuscript.

\section{Ethics approval and consent to participate}

The ethical clearance for primary data was obtained from the authorities of the Ethics Commitee of the National Institute of Health Reserach and Development, Ministry of Health of Indonesia (number LB.02.01/5.2/KE.020/ 2017).

\section{Consent for publication}

Not applicable.

\section{Competing interests}

The authors declare that they have no competing interests.

\section{Publisher's Note}

Springer Nature remains neutral with regard to jurisdictional claims in published maps and institutional affiliations.

\section{Author details}

${ }^{1}$ Institute for Vector and Reservoir Control Research and Development (NIHRD-MoH), Salatiga, Indonesia. ${ }^{2}$ Université de Montpellier, Montpellier, France. ${ }^{3}$ HydroSciences Montpellier (HSM), Institut de Recherche pour le Développement (IRD), CNRS, Université de Montpellier, Montpellier, France. ${ }^{4}$ Health Research and Development unit Baturaja, Baturaja, South Sumatra, Indonesia. ${ }^{5}$ Department of Parasitology, Faculty of Medicine, Gadjah Mada University, Yogyakarta, Indonesia. ${ }^{6} \mathrm{CIRAD}$, Intertryp, Montpellier, France. ${ }^{7}$ IES, Université de Montpellier-CNRS, Montpellier, France.

Received: 17 September 2018 Accepted: 28 December 2018 Published online: 08 January 2019

\section{References}

1. Cook S, Moureau G, Kitchen A, Gould EA, de Lamballerie X, Holmes EC, et al. Molecular evolution of the insect-specific flaviviruses. J Gen Virol. 2012;93:223-34.

2. Soedarmo SP, Wuryadi S, Suroso T. Japanese encephalitis in Indonesia. In: Regional workshop on control strategies for Japanese encephalitis. Nonthaburi, Thailand, 4-6 October; 1994.

3. Schuh AJ, Guzman H, Tesh RB, Barrett ADT. Genetic diversity of Japanese encephalitis virus isolates obtained from the Indonesian archipelago between 1974 and 1987. Vector Borne Zoonotic Dis. 2013:13:479-88.

4. Pan X-L, Liu H, Wang H-Y, Fu S-H, Liu H-Z, Zhang H-L, et al. Emergence of genotype I of Japanese encephalitis virus as the dominant genotype in Asia. J Virol. 2011:85:9847-53.

5. Fan YC, Lin JW, Liao SY, Chen JM, Chen YY, Chiu HC, et al. Virulence of Japanese encephalitis virus genotypes I and III, Taiwan. Emerg Infect Dis. 2017;23:1883-6.

6. Santhosh SR, Parida MM, Dash PK, Pateriya A, Pattnaik B, Pradhan HK, et al. Development and evaluation of SYBR Green I-based one-step real-time RTPCR assay for detection and quantitation of Japanese encephalitis virus. J Virol Methods. 2007;143:73-80.

7. Gao X, Liu H, Wang H, Fu S, Guo Z, Liang G. Southernmost Asia is the source of Japanese encephalitis virus (genotype 1) diversity from which the viruses disperse and evolve throughout Asia. PLoS Negl Trop Dis. 2013;7:e2459.

8. Zhang DX, Hewitt GM. Assessment of the universality and utility of a set of conserved mitochondrial COI primers in insects. Insect Mol Biol. 1997:6:143-50

9. Nitatpattana N, Dubot-Peres A, Ar Gouilh M, Souris M, Barbazan P, Yoksan S, et al. Change in Japanese encephalitis virus distribution, Thailand. Emerg Infect Dis. 2008:14:1762-5.

10. Whelan P, Hayes G, Tucker G, Carter J, Haigh B, Whelan P, et al. The detection of exotic mosquitoes in the Northern Territory of Australia. Arbovirus Res Aust. 2001:8:395-404

11. Han N, Adams J, Fang W, Liu SQ, Rayner S. Investigation of the genotype III to genotype I shift in Japanese encephalitis virus and the impact on human cases. Virol Sin. 2015:30:277-89.

12. Zhang J-S, Zhao Q-M, Guo X-F, Zuo S-Q, Cheng J-X, Jia N, et al. Isolation and genetic characteristics of human genotype 1 Japanese encephalitis virus, China, 2009. PLoS One. 2011;6:e16418.

Ready to submit your research? Choose BMC and benefit from:

- fast, convenient online submission

- thorough peer review by experienced researchers in your field

- rapid publication on acceptance

- support for research data, including large and complex data types

- gold Open Access which fosters wider collaboration and increased citations

- maximum visibility for your research: over $100 \mathrm{M}$ website views per year

At $\mathrm{BMC}$, research is always in progress.

Learn more biomedcentral.com/submissions 